\title{
Designing Remuneration Systems of Organizations for Sustainable HRM: The Core Characteristics of an Emerging Field
}

\author{
Gintautas Radvila \\ School of Economics and Business Kaunas University of Technology \\ K. Donelaičiog. 73, 44029, Kaunas, Lithuania \\ E-mail: gintautas.radvila@ktu.edu \\ Violeta Šilingienè \\ School of Economics and Business, Kaunas University of Technology \\ K. Donelaičiog. 73, 44029, Kaunas, Lithuania \\ E-mail: violeta.silingiene@ ktu.lt
}

Received: April 9, 2020 Accepted: May 7, 2020 Online published: May 25, 2020

doi:10.5296/ijhrs.v10i2.17086ＵRL: https://doi.org/10.5296/ijhrs.v10i2.17086

\begin{abstract}
Successful business trends in the $21^{\text {st }}$ century cover new factors where economic viability and sustainability should address not only the economic criterion, but also the human managerial one. This leads to the creation of effective sustainable work systems including remuneration systems as a part of sustainable human resource management. The basic research object of sustainable work systems is work intensity, which covers many possible approaches including remuneration systems of organizations. Effective remuneration systems enhance the performance and contribution of employees by controlling labor cost, motivating employees and involving them in organizational processes. Nevertheless, there is a lack of evidence for the sustainability of both theoretical and empirical research of remuneration systems. This article pursues validating theoretical concepts related to sustainable human resource management (SHRM) and remuneration systems by empirical disclosure of the expression of SHRM principles in the characteristics of remuneration systems. The purpose of this paper is to reveal the characteristics of remuneration systems of organizations in real SHRM in enterprises in Lithuania. In order to achieve this, a qualitative study was conducted using
\end{abstract}


semi-structured interviews with 21 corporate HR managers. The study empirically substantiated the relationship between the principles of sustainable human resource management and remuneration characteristics. Results disclosed that as many as 10 of the 12 SHRM principles allow to identify the remuneration system as a sustainable work system. All the identified characteristics of the remuneration system reveal various principles of SHRM through different features and indicators. Furthermore, it confirms the economic, social and environmental nature of sustainable remuneration systems.

Keywords: sustainable human resource management, remuneration, remuneration system, characteristics of remuneration system

\section{Introduction}

Sustainability and sustainability development are relatively new phenomena which were introduced in the Brundtland report in 1987. Based on different analyses it could be stated that this report has received one of the highest citation rate focusing sustainability. Authors such as Olawumi and Chan (2018) executed a wide-range scientometric review of global research on sustainability and sustainable development revealing increased attention to this topic by government agencies, academics, practitioners and international organizations. Keyword cluster network analysis disclosed that one of two keywords is 'sustainable development', equal to 'sustainability indicator'. Sustainable development opened new venues for a wide range of interpretation in context of sustainability. Likely, the most cited author on this topic is Lélé (1991). Different perspectives on sustainable development created conditions to explore and develop a more complex and more accurate field of research on the concept of sustainability.

Based on this research, authors address sustainability in human resource management. A wide variety of similar abbreviations is being used in scientific literature, such as sustainable HRM, human resource sustainability, sustainable management of human resource and others. For the purpose of clarity, authors use the term of SHRM, proposed by Ehnert, Parsa, Roper, Wagner and Muller-Camen (2015), which is being 'defined as the adoption of HRM strategies and practices that enable the achievement of financial, social and ecological goals, with an impact inside and outside of the organization and over a long-term time horizon while controlling for unintended side effects and negative feedback'. The same authors confirm that sustainability has a clear connection to organization performance. Macke and Genari (2018) executed a systematic review on sustainable human resource management and revealed that organizational sustainability is tightly dependent on human resource management practice where the sustainability concept in HRM is a mediator factor or a final objective. This leads to the general idea that changes in modern times challenge the development of society and organizations focusing not only on economic qualitative growth (Stankevičiūtè, 2015), but also on existing sustainability-targeting systems, processes and human resources. SHRM itself is multidimensional as authors disclose concepts of "green" human resource management (Renwick at al., 2012; Opatha, \& Arulrajah, 2014), ethical human resource management (Greenwood, \& Simmons, 2004, Legge, 1998), socially responsible human resource management (Becker, 2011, Becker, \& Smith, 2012) and 
sustainable work systems (Shani, \& Docherty 2003, Kira, 2003). The article further develops the ideas of sustainability and their expression in human resource management systems, in this case, the remuneration system. The basic research object of sustainable work systems is work intensity, which covers many possible approaches including remuneration systems of organizations. Effective remuneration systems enhance performance and contribution of employees by controlling labor cost, motivating employees and involving them in organizational processes.

However, both theoretical and empirical studies observe a lack of evidence for the sustainability of remuneration systems. The scientific issues of remuneration systems in the research of foreign authors are mainly analyzed in relation to the elements that comprise their structure. Still, there is insufficient knowledge regarding the complex approach on the characteristics that identify remuneration systems. Some possible approaches could be found in Armstrong (2009), Armstrong and Murlis (2007), Wang, Thornhill, Zhao (2016), Milkovich, Newman, Gerhart (2014), Martocchio (2013), Biswas (2013), Costa, Passos, Bakker (2014) and other works. It should be noted that so far, not only in Lithuania but also worldwide, there is a lack of systematic research focused on the expression of the characteristics of remuneration systems in the context of sustainable human resource management. In Lithuania, research on remuneration systems covers only two problem areas: aspects of the system of fair payment for work principle with related legal principles, and a systemic evaluation of the factors of external and internal environment, which influence the remuneration of labor.

There is a lack of empirical research covering the managerial approach of remuneration systems regarding sustainability of HRM. This is a new venue of research and authors have already disclosed dependencies between SHRM and remuneration systems where sustainable work systems is a key object or even the driving force. Taking this into consideration, it is necessary to practically identify the key characteristics which lead to SHRM. Radvila and Silingiene (2018) present an already developed theoretical remuneration system construct which is based on five characteristics of remuneration system: the orientation towards remuneration goals, the purposes of the remuneration system, the formalization of the remuneration system, the orientation of the remuneration system towards performance and the flexibility of the remuneration system. The disclosed gap of knowledge in SHRM in the context of the remuneration system and its principles compiled the scientific problem of the article - what characteristics of remuneration systems of organizations affect SHRM.

The purpose of this paper is to reveal the characteristics of remuneration systems of organizations in real sustainable human resource management in enterprises in Lithuania. The aim of this article is to confirm the theoretical links between sustainable human resource management and remuneration systems by empirically revealing the expression of the principles of sustainable human resource management in the characteristics of remuneration systems.

\section{Literature Review}

In order to reveal the characteristics of remuneration systems which affect SHRM, the 
authors have conducted scientific literature analysis and synthesis. The former focuses on scientific development of the sustainability concept approaching working systems (incl. remuneration systems). The latter contributes to the disclosure of the characteristics of remuneration systems.

\subsection{Sustainability Concept Approaching Working Systems}

Scientific literature analysis revealed that the concept of sustainability and its development started in 1987. The Brundtland Report has been used the most and was the key to starting this scientific venue. The next noteworthy author who reviewed the sustainable development venue was Lélé (1991). She revealed a wide range of interpretation of sustainability which created a new possible venue for sustainability development. The first valuable implications of sustainable human resource management could be identified in Wright and McMahan (1992). Investigating different perspectives towards sustainability in HRM it has been identified that likely the first scientific venue of sustainable work systems started in 1999 (Eijnatten, 2000). Authors such as Docherty et al. (2002) elaborate even more on sustainable work systems, creating conditions for further research. Still, no relevant sustainable approach towards remuneration systems has been discovered. Some terms, such as sustainable wages or sustainable salary, have been used but the content does not provide a systematic approach through work systems. Radvila and Silingiene (2018) have theoretically grounded the dependency between remuneration systems and SHRM. Based on scientific research, the development of sustainability towards the remuneration issue is presented in a timeline:

- 1987 - Sustainability and sustainability development;

- 1992 - Sustainable human resource management;

- 1999 - Sustainable work systems;

- Likely 2018 - Sustainable approach towards remuneration systems.

Theoretical analysis of interdependency between SHRM and remuneration systems has been revealed by Radvila and Silingiene (2018). Emphasis has been placed on the relationship between SHRM and the remuneration system through the influence of SHRM principles (Stankevičiūte, 2015) on both the sustainability of work systems (at the same time the remuneration system) and the expression of remuneration characteristics. This part of analysis created additional implications to disclose the characteristics of remuneration systems and their relationship to SHRM principles (Figure 1). 
Sustainable human resource management

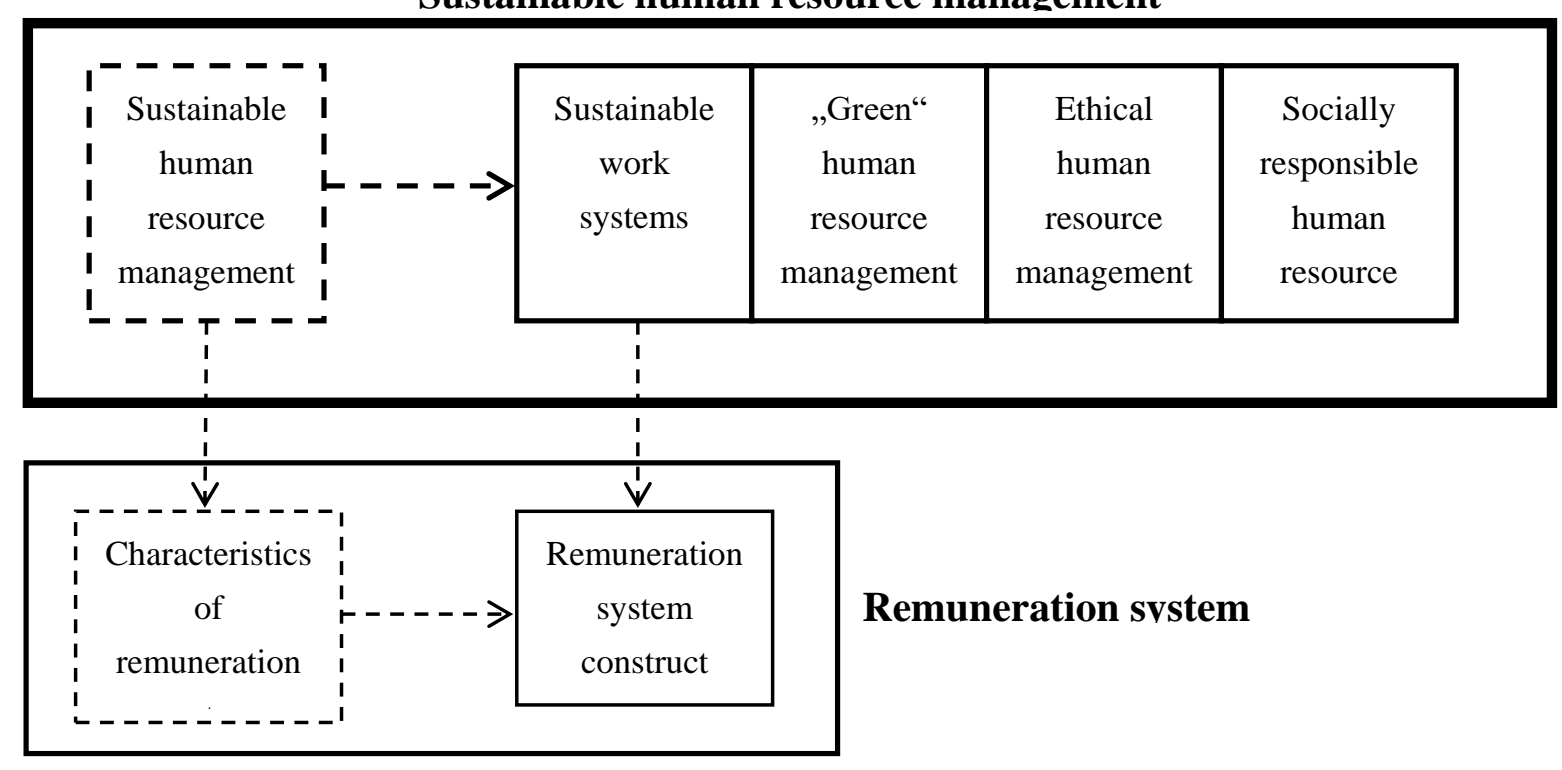

Figure 1. Sustainable human resource management

To summarize, it is necessary to state that after 1987, parallel researches have been executed covering different venues of sustainability. The authors focus only on the sustainable approach towards remuneration systems by filtering knowledge through the sustainability architecture. This has led to the disclosure of the characteristics of remuneration systems.

\subsection{Characteristics of Remuneration Systems}

Scientific literature analysis revealed that the characteristics of the remuneration system are not clearly defined. Different authors use different terms such as parameters, characteristics, principles, etc. There are also no clear systematic studies that precisely define the limits of remuneration system characteristics. This synthesis and systematization is necessary to reveal the manifestation of remuneration characteristics. The analysis of remuneration system characteristics disclosed a multidimensional and multifold managerial approach which has not been used in any previous research. In the theoretical approach the authors have disclosed the following key remuneration characteristics:

- Orientation towards remuneration system goals.

- Purposes of the remuneration system.

- Formalization of the remuneration system.

- Remuneration system orientation towards performance.

- Flexibility of the remuneration system.

The first one discloses perspectives of soft and hard remuneration goals. Some authors such as Wang, Thornhill and Zhao (2016) executed research in a pay for performance study covering outcome evaluations assessment and employee participation. It disclosed a trend that systems focused on hard remuneration goals are more applicable as opposed to soft goals. 


\section{MInstitute Macrothink $_{\text {Intion }}$}

International Journal of Human Resource Studies

ISSN 2162-3058

2020, Vol. 10, No. 2

The disclosure of this characteristic has been supported by Kuvaas, Buch and Dysvik (2018), Holmström (2017), Wang, Thornhill and Zhao (2016) Wang, Zhao and Thornhill (2015), Armstrong (2009), Armstrong and Cummins (2011), Flannery, Hofrichter and Platten (1996) and others.

The purposes of the remuneration system disclosed two focus groups. The first is organization-focused and the other employee-focused. This kind of approach has been generated by the contribution of Larkin (2019), Trif and Geary (2016), Sundberg (2015), Milkovich, Newman and Gerhart (2014), Martocchio (2013), Lipinskienė (2012) Armstrong (2009), Vanagas (2009), Armstrong and Murlis (2007), Henderson (2006), Mačernytė-Panomariovienè (2003), Dubinas (1996) and others. No generic trends regarding current business are being revealed.

The third characteristic addresses the relationship between individual pay and pay structures of organization. Given this, authors mostly target separate elements or their system towards well-formalized remuneration systems. They have been disclosed by Fuller and Cooke (2018), Thanassoulis and Tanaka (2018), Abraham (2017), Milkovich, Newman and Gerhart (2014), Armstrong (2009), Armstrong and Murlis (2007) and others.

The characteristic of remuneration system orientation towards performance stated quite a different targeting for implementation. At this point, it is more likely hierarchy-type structure characteristic which leads to success covering the step by step approach. Key focus lays on the successful transfer from individual to company performance criterion. Such approach could be supported by Ferreira (2019), Gryglewicz, Hartman-Glaser and Zheng (2018), Sauer, Rodgers and Becker (2018), Makikangas, Aunola, Seppala and Hakanen (2016), Costa, Passos and Bakker (2014), Martocchio (2013), Biswas (2013), Armstrong and Cummins (2011) and others.

The last one has no clear point to be revealed. Most of the flexibility indicators in remuneration systems could be identified in the usage of pay schemes grading and time consumption to transfer from one to another. This could be grounded by Babecký, Galuščák and Žigraiová (2017), Schmitt-Grohé and Uribe (2016), Favilukis and Lin (2016), Milkovich, Newman and Gerhart (2014), Armstrong (2009), Armstrong and Taylor (2017) and others.

To summarize, the authors created a semi-structural interview to confirm existing characteristics of remuneration systems. Additionally, no final set of characteristics had been defined. Given this, the disclosure of characteristics created conditions to deepen knowledge in remuneration issues and assess possible theoretical and practical venues for further research.

\section{Methodology}

\subsection{Data Sample and Collection}

The complexity of the characteristics of the remuneration system as the object of the study, the lack of existing empirical data and the nature of the study required qualitative research access (Poria, Reichel, \& Brandt, 2011). Afterwards, the semi-structured interview method 
was selected and the HR unit managers or the HR functional specialists of 21 companies were interviewed. Only Lithuanian companies were selected on the basis of their diversity idea to cover the different dimensions that characterize them: type of activity, size, sector, level of centralization of HR function. Table 1 presents the profile of the companies and respondents who participated in the survey.

Table 1. Profile of organizations and respondents

\begin{tabular}{|c|c|c|c|c|c|}
\hline $\begin{array}{l}\text { Respondent } \\
\text { Number }\end{array}$ & $\begin{array}{l}\text { Organization } \\
\text { type of } \\
\text { activity }\end{array}$ & $\begin{array}{l}\text { Organization } \\
\text { Sector }\end{array}$ & $\begin{array}{l}\text { Organization } \\
\text { Size }\end{array}$ & $\begin{array}{l}\text { HRM } \\
\text { Function }\end{array}$ & $\begin{array}{l}\text { Respondent } \\
\text { Position }\end{array}$ \\
\hline $\mathrm{R} 1$ & Trade & Private & Approx. 250 & $\begin{array}{l}\text { HRM } \\
\text { Department }\end{array}$ & Head of HR \\
\hline $\mathrm{R} 2$ & Services & Private & Approx. 800 & $\begin{array}{l}\text { HRM } \\
\text { Department }\end{array}$ & $\begin{array}{l}\text { Business } \\
\text { partner for } \\
\text { Staffing }\end{array}$ \\
\hline R3 & Services & Private & Approx. 2000 & $\begin{array}{l}\text { HRM } \\
\text { Department }\end{array}$ & $\begin{array}{l}\text { Head of } \\
\text { Accounting }\end{array}$ \\
\hline $\mathrm{R} 4$ & Services & Private & Approx. 2000 & $\begin{array}{l}\text { HRM } \\
\text { Department }\end{array}$ & $\begin{array}{l}\text { Head of } \\
\text { remuneration } \\
\text { unit }\end{array}$ \\
\hline R5 & Manufacturing & Private & Approx. 50 & $\begin{array}{l}\text { HRM } \\
\text { Department }\end{array}$ & Head of HR \\
\hline R6 & Manufacturing & Private & Approx. 200 & $\begin{array}{l}\text { HRM } \\
\text { Department }\end{array}$ & Head of HR \\
\hline $\mathrm{R} 7$ & Services & Private & Approx. 200 & $\begin{array}{l}\text { HRM } \\
\text { Department }\end{array}$ & Head of HR \\
\hline $\mathrm{R} 8$ & Trade & Private & Approx. 7000 & $\begin{array}{l}\text { HRM } \\
\text { Department }\end{array}$ & $\begin{array}{l}\text { Business } \\
\text { partner for } \\
\text { Staffing }\end{array}$ \\
\hline R9 & Services & Private & Approx. 40 & $\begin{array}{l}\text { No HRM } \\
\text { department }\end{array}$ & Deputy Head \\
\hline $\mathrm{R} 10$ & Manufacturing & Private & Approx. 10 & $\begin{array}{l}\text { No HRM } \\
\text { department }\end{array}$ & $\begin{array}{l}\text { Chief } \\
\text { constructor }\end{array}$ \\
\hline $\mathrm{R} 11$ & Trade & Private & Approx. 1200 & $\begin{array}{l}\text { HRM } \\
\text { Department }\end{array}$ & $\begin{array}{l}\text { Deputy } \\
\text { Director of } \\
\text { Personnel }\end{array}$ \\
\hline
\end{tabular}




\begin{tabular}{|c|c|c|c|c|c|}
\hline $\mathrm{R} 12$ & Manufacturing & Private & Approx. 200 & $\begin{array}{l}\text { HRM } \\
\text { Department }\end{array}$ & HR specialist \\
\hline $\mathrm{R} 13$ & Services & Public & Approx. 260 & $\begin{array}{l}\text { HRM } \\
\text { Department }\end{array}$ & Head of HR \\
\hline R14 & Manufacturing & Private & Approx. 500 & $\begin{array}{l}\text { HRM } \\
\text { Department }\end{array}$ & Head of HR \\
\hline $\mathrm{R} 15$ & Services & Public & Approx. 270 & $\begin{array}{l}\text { HRM } \\
\text { Department }\end{array}$ & $\begin{array}{l}\text { Head of the } \\
\text { company }\end{array}$ \\
\hline R16 & Manufacturing & Private & Approx. 1500 & $\begin{array}{l}\text { HRM } \\
\text { Department }\end{array}$ & Head of HR \\
\hline $\mathrm{R} 17$ & Manufacturing & Private & Approx. 400 & $\begin{array}{l}\text { No HRM } \\
\text { department }\end{array}$ & $\begin{array}{l}\text { Head of the } \\
\text { company }\end{array}$ \\
\hline R18 & Manufacturing & Private & Approx. 100 & $\begin{array}{l}\text { HRM } \\
\text { Department }\end{array}$ & Head of HR \\
\hline R19 & Manufacturing & Private & Approx. 30 & $\begin{array}{l}\text { HRM } \\
\text { Department }\end{array}$ & HR specialist \\
\hline $\mathrm{R} 20$ & Services & Public & Approx. 140 & $\begin{array}{l}\text { HRM } \\
\text { Department }\end{array}$ & $\begin{array}{l}\text { HR chief } \\
\text { specialist }\end{array}$ \\
\hline $\mathrm{R} 21$ & Manufacturing & Private & Approx. 80 & $\begin{array}{l}\text { No HRM } \\
\text { department }\end{array}$ & $\begin{array}{l}\text { Head of } \\
\text { production }\end{array}$ \\
\hline
\end{tabular}

\subsection{Data Analysis}

Based on the ideas of various authors in qualitative research (Mayring, 2014), a qualitative content analysis approach was chosen for the analysis of data of the semi-structured interview. To determine remuneration system characteristics after the semi-structured interview, the subsequent research steps were followed:

Step 1: development of a questionnaire of the semi-structured interview. Based on the theoretical identification of remuneration system characteristics, key topics and questions were foreseen in advance, leaving room for additional refinement questions. The structure of the interview consisted of 5 blocks of questions corresponding to the characteristics of the remuneration system. The main interview questions are presented in Table 2. 
Table 2. The main interview questions

\begin{tabular}{|l|l|}
\hline Characteristics of Remuneration System & Main Interview Questions \\
\hline $\begin{array}{l}\text { Orientation towards remuneration system } \\
\text { goals }\end{array}$ & $\begin{array}{l}\text { What determines the salary in your } \\
\text { organization? }\end{array}$ \\
\hline Purposes of the remuneration system & $\begin{array}{l}\text { What are your organization's priority } \\
\text { objectives or } \\
\text { employee-oriented) of the remuneration } \\
\text { system? }\end{array}$ \\
\hline Formalization of the remuneration system & $\begin{array}{l}\text { What is the level of formalization of your } \\
\text { company's remuneration system, is it based } \\
\text { on job evaluation? }\end{array}$ \\
\hline $\begin{array}{l}\text { Remuneration system orientation towards } \\
\text { performance }\end{array}$ & $\begin{array}{l}\text { What are the incentive plans in your } \\
\text { company? }\end{array}$ \\
\hline Flexibility of the remuneration system & $\begin{array}{l}\text { Please describe how quickly your } \\
\text { organization would be able to transform its } \\
\text { remuneration system. }\end{array}$ \\
\hline
\end{tabular}

Step 2: Conducting the interview. The longest interview lasted 90 minutes. On average, the semi-structured interviews lasted about 40 minutes, with a total interview time of 19 hours 25 min. The interviews were conducted in Lithuanian, recorded and later transcribed.

Step 3: Transcription of the data obtained during the interviews. During this step, audio transcripts were analyzed by writing down the interview transcripts.

Step 4: Defining the unit of analysis, construction of the categories and construction of the coding scheme. A sentence was chosen as the unit of analysis for the interview texts. The category was selected as the highest level of coding and the subcategory as the lowest level of coding. Subcategories were obtained by a heuristic reading of the sentence of the research participants, abstracting the information contained therein and creating a subcategory for it. Subcategories relating to a single idea were merged into a single category and defined by the wording in that category. Multiple categories were merged into a theme.

Step 5: Encoding the whole text. In 21 electronic files the interview texts were analysed uniformly under the coding scheme - subcategory, category and theme.

Step 6: Evaluation of coding integrity. Coded texts were read many times, the names of subcategories and categories, and the categorization of subcategories into themes were revised.

Step 7: Summary of the encoded material. The contents of the coded texts are presented in the 
constructed tables.

\section{Results}

This section presents how the characteristics of remuneration systems are expressed in practice: the orientation towards goals, the purposes of the remuneration system, the level of formalization, the nature of incentive plans, and the flexibility. This chapter is divided into 5 sections that show in detail how the characteristics of the remuneration system are realized in the real remuneration systems of companies. Each subsection contains tables with sub-categories and categories for each characteristic grouped into themes.

\subsection{Orientation Towards Remuneration Goals}

The orientation towards remuneration goals is linked to the essential parameters on which the level of pay depends. Analyzing the interviewees' responses to the question of what determines the salary in your organization, 2 categories were extracted: hard remuneration goals and soft remuneration goals (Table 3).

Table 3. Sub-themes and themes that relate to the orientation towards remuneration goals

\begin{tabular}{|l|l|l|}
\hline Sub-Themes & Themes & Characteristic \\
\hline $\begin{array}{l}\text { additional employee responsibilities; } \\
\text { employee initiative; competences; } \\
\text { professional knowledge; communication } \\
\text { skills }\end{array}$ & soft remuneration goals & $\begin{array}{l}\text { orientation towards } \\
\text { remuneration goals }\end{array}$ \\
\cline { 1 - 1 } $\begin{array}{l}\text { individual sales results; productivity; } \\
\text { number of orders; number of shipments } \\
\text { delivered; number of errors; the benefit } \\
\text { to the enterprise of the employee's } \\
\text { financial result }\end{array}$ & hard remuneration goals & \\
\hline
\end{tabular}

The two distinguished categories reflect different estimates of the remuneration goal targets of the respondent firms. The answers belonging to the first category revealed the dependence of remuneration on the competences and abilities of the employees. Emphasizing the soft remuneration goals, respondents note that wage levels in their organization depend on ' $<\ldots>$ professional knowledge, <...> communication skills' (R15); '<..> remuneration depends on the competencies of the employee. The longer he works, the more he earns competencies that are rewarded in grading systems of position' (R3). During the interviews, it was noticed that organizations are trying to appreciate employees: '<...> doing very well, maybe taking on some additional responsibilities, maybe trying very hard $<_{\ldots} . .>$ accordingly to the employee's initiative <...> do more, we can also encourage that. '(R6).

The second category of answers emphasizes the dependence of remuneration on employee performance, productivity and contribution to the company's results. Respondents' answers 
illustrate the hard remuneration goals: '< .. > If we talk about pharmacy staff, then variable pay is not stable depending on individual sales results and is calculated on monthly basis.'; $'<\ldots>$ Variable pay of employees of the logistics center is being calculated each month on the basis of the individual performance of each employee.'; '<...> In the logistics center, pay changes every month, that consists of the base pay adding the variable pay part for work done: number of orders, number of goods collected, number of shipments delivered, number of goods received, number of errors, etc.' (R11). The statements made by the respondents reveal that the salaries of the investigated organizations depend on the individual performance of the employees, which includes the fulfilment of norms, fulfilment of individual and team goals, sales results and so on.

To summarize this remuneration characteristic, it is necessary to note that organizations clearly indicate their focus on remuneration system goals. Likely, this only supports that different organizations have different perspectives on employees. Thus, these remuneration goals have relations to organizational focus. In general, we could describe that organizational focus, which is based on process efficiency, likely corresponds to soft remuneration goals. Contrary to this, the organizational focus based on results likely rearranges remuneration based on hard remuneration goals.

\subsection{The Purposes of the Remuneration System}

The purposes of the remuneration system is related to the priorities of the remuneration system goals. Analyzing the respondents' answers to the question regarding their organisation's priority objectives (organization- or employee-oriented) of remuneration system extracted 3 categories (themes): organization-focused, employee-focused and alignment of organizational and employee goals (Table 4).

Table 4. Sub-themes and themes that relate to purposes of the remuneration system

\begin{tabular}{|l|l|l|}
\hline Sub-Themes & Themes & Characteristic \\
\hline $\begin{array}{l}\text { involvement in internal organizational } \\
\text { processes; labor cost control; } \\
\text { implementation of the organization's } \\
\text { strategy; performance improvement }\end{array}$ & $\begin{array}{l}\text { Ourposes of the } \\
\text { remuneration } \\
\text { system }\end{array}$ \\
\cline { 1 - 1 } $\begin{array}{l}\text { motivating employees; remuneration } \\
\text { for the result achieved; attracting and } \\
\text { retaining the best employees }\end{array}$ & Employee-focused & \\
\cline { 1 - 1 } $\begin{array}{l}\text { the balance between the goals of the } \\
\text { organization and the employees; } \\
\text { collaborative organization }\end{array}$ & alignment of organizational \\
and employee goals & \\
\hline
\end{tabular}

The three distinguished categories reflect different priorities for the purposes of remuneration 
systems. The first category of answers highlights organization-focused purpose, prioritizing employee engagement in internal organizational processes, controlling labor costs, and implementing an organization strategy. Emphasizing the organization-focused purposes, respondents note that in their organization, ' $<\ldots>$ the purpose of the remuneration policy is still incorporated within the organization $<\ldots>$ ' (R1). During the interviews, it was noticed that in organizations, employees provide ' $<\ldots>$ their thoughts, ideas on some performance improvement process or how to control labor costs $<\ldots$. ' (R5).

The answers belonging to the second category emphasize employee-focused remuneration system goals, giving priority to the motivation of employees, remuneration for the achieved result. These purposes are illustrated by interviewees' responses: '<...> because an organization needs to achieve business results and in order to achieve it, it needs $\langle\ldots\rangle$ to attract the best employees according to the criteria they have set or retain its best employees' (R1); ' $<\ldots>$ the overall objective of the company is to attract and retain the best employees and the remuneration system is an integral part. We are committed to motivating our employees to keep our business successful.' (R4). The statements made by the respondents have revealed that the remuneration of the investigated organizations depend on personal motivation of the employees both to achieve good results and to have the best employees.

The third category of responses also emerged, wherein respondents noted that a balance was struck between the focus of the purposes of the organization and the employees: ' $<\ldots>$ there is a balance between the purposes of the employee and the organization, $\langle\ldots\rangle$ we are a collaborative organization' $(R 2) ; \quad$ ' $<\ldots>$ remuneration system purposes are in the middle, $<\ldots>$ ', it is important that ' $<\ldots>$ both the employee and the organization would be happy' (R5).

In summary, it could be stated that a new category has been revealed which comprises the alignment of organizational and employee goals. Moreover, some of the indicators disclosed that this type of characteristic might have a decent grading system. The authors of the article clarified this characteristic by creating 3 categories which are structured based on the measurement tool they have used. Still, it is noted that adjustments to the current assessment tool of characteristics of remuneration system are needed.

\subsection{The Level of Formalization of the Remuneration System}

The level of formalization of the remuneration system is linked to the clarity of its structure definition. Respondents' answers to the question whether the remuneration system in the organization is based on job evaluation were extracted from 2 categories: formalized and semi- or completely non-formalized remuneration system (Table 5). 
Table 5. Sub-themes and themes that relate to the formalization of the remuneration system

\begin{tabular}{|l|l|l|}
\hline Sub-Themes & Themes & Characteristic \\
\hline $\begin{array}{l}\text { a clearly defined remuneration } \\
\text { structure; remuneration structure } \\
\text { covers all work / positions of the } \\
\text { organization; individual payrolls } \\
\text { integrated into the overall payroll } \\
\text { structure; the remuneration system is } \\
\text { based on job evaluation; the payroll } \\
\text { system is documented in the internal } \\
\text { records of the organization }\end{array}$ & $\begin{array}{l}\text { Wormalization of the } \\
\text { remuneration system }\end{array}$ & \\
\hline $\begin{array}{l}\text { only individual payrolls are } \\
\text { recognized; wages are defined only in } \\
\text { the employment contract; pay is based } \\
\text { on a confidential agreement with the } \\
\text { head }\end{array}$ & $\begin{array}{l}\text { semi- or completely } \\
\text { non-formalized }\end{array}$ & \\
\hline
\end{tabular}

The two categories reflect the different levels of formalization of corporate remuneration systems. Responses to the first category highlight well-defined remuneration systems, where the payroll structure covers all the jobs / positions in the organization and the individual payrolls are integrated into the overall payroll structure. Emphasizing the formalized remuneration system, respondents note that their organization's ' $<\ldots>$ remuneration system clearly defines each position and its payroll. <...> established the system of remuneration $\langle\ldots\rangle$ is set out in the description of the procedure for remuneration. Once it is known, all employees must sign' (R7). During the interviews, it was noticed that the organizations try to apply the same payroll rates to the same position: '<...>The salaries of the employees in the same position in the shop are the same. This means that two grocery workers receive the same fixed salary $<\ldots>^{\prime}$ (R8). In organizations with a formalized remuneration system, positions are evaluated and graded: ' $<\ldots>$ the remuneration system is based on job evaluation and has a high level of formalization' (R11); '<...> roles <...> are evaluated based on the Hay group level methodology and each of our roles has a certain level <...>' (R 2).

The remuneration systems mentioned in the second category of answers are non-formalized or semi-formalized, they only recognize individual payroll, and pay is defined only in the employment contract. Responses illustrate this category of remuneration systems: ' $<$... Remuneration system in the enterprise is semi-formalized in that there is payroll distribution by jobs, <...> however, there are different payrolls in each job, subjected by a confidential agreement with the head.'; '<...> The payroll of an employee shall be determined when applying for a specific post during the first job interview and shall be recorded (fixed) in the employment contract.' (R10). '<...> It is, in fact, everyone's personal matter and agreement $<. . .>$. With us individually on employment contracts, when it comes to work and 
the payroll is agreed upon ' (R12). The statements made by the respondents have revealed that the remuneration of the investigated organizations is primarily based on an individual agreement between the employee and the manager.

Hence, it might be stated that the main focus goes on individual positions and payroll for them, yet it lacks systematic approach. Some of the respondents confirmed having well-formalized remuneration systems. In order to have such, additional resources should be spent. Given this, big enterprises might have these additional resources and it creates added value by simplifying remuneration system and processes. Small companies, having not as many employees, will not receive such added value as the big ones from well-formalized remuneration system and only individual payrolling is being set up.

\subsection{The Remuneration System Orientation Towards Performance}

The nature of the objectives of the remuneration system towards performance is linked to the essential parameters on which the level of pay depends. Analyzing interviewees' responses to the question of what the incentive plans in your company are, 3 categories were extracted: individual, team, and organizational promotion plans (Table 6).

Table 6. Sub-themes and themes that relate to remuneration system orientation towards performance

\begin{tabular}{|l|l|l|}
\hline Sub-Themes & Themes & Characteristic \\
\hline $\begin{array}{l}\text { the remuneration system focuses on } \\
\text { individual productivity (quantity, } \\
\text { quality); monthly sales, compliance } \\
\text { with occupational safety } \\
\text { requirements; work discipline; } \\
\text { employee behavior is directed } \\
\text { towards good job performance }\end{array}$ & $\begin{array}{l}\text { plans } \\
\text { remuneration system } \\
\text { orientation towards } \\
\text { performance }\end{array}$ \\
\hline $\begin{array}{l}\text { the remuneration system is oriented } \\
\text { towards the satisfaction of the } \\
\text { consumers, saving of the pay costs; } \\
\text { saving of material resources; accident } \\
\text { prevention, cost reduction of services; } \\
\text { productivity of teamwork }\end{array}$ & Team incentive plans \\
\hline $\begin{array}{l}\text { turnover, cost savings; market growth; } \\
\text { sales revenue; execution of the } \\
\text { production plan; yield }\end{array}$ & $\begin{array}{l}\text { Organization incentive } \\
\text { plans }\end{array}$ & \\
\hline
\end{tabular}

The three categories reflect the different orientations of incentive plans integrated into remuneration systems. Responses to the first category mention individual incentive plans that 
focus on individual productivity (quantity, quality), monthly sales, workplace safety compliance, and job discipline. During the interviews, it was noticed that organizations are trying to encourage employees to evaluate ' $<\ldots>$ Each personally created spoilage. The benefits of everyone personally. Everyone's personal effort is shown.'(R5). With emphasis on individual incentive plans, respondents note the individual contribution of employees to performance determined through annual evaluation interviews: ' $<$... $>$ Individual payroll depend on annual performance evaluation. It shall be recorded throughout the year whether an employee has achieved results $<\ldots>^{\prime}(\mathrm{R} 4)$. It was also noted that individual incentive plans are not only result- but also good performance-oriented ' $<\ldots>$ not only in numbers but also in employee behavior <... >'(R4).

Responses to the second category of answers emphasize team-based incentive plans that measure consumer satisfaction, salary cost savings, material resource savings, accident avoidance and service cost reduction. Interviewees' responses illustrate team-based incentive plans: '<...> indicators do not depend solely on the individual; they often depend on the unit, shop, and team working in the store' (R11); '<...> works as a team, we also look at the productivity of teamwork' (R5). The statements made by the respondents highlight features of team incentive plans such as resource efficiency and the maintenance of the unit's payroll: ' $<\ldots>$ indicators have more to do with $<\ldots>$ the division's goals of how to use resources saving and efficiently, increase profitability, maintain the division's remuneration budget and so on' (R11).

The third category of responses includes organization incentive plans that focus on the organization's profit, cost savings, market growth and sales revenue. They are illustrated by interviewees' responses to the indicators that ' $<\ldots>$ relate to the profitability of the enterprise and the turnover of the firm' (R1); focuses on '<...> profit, cost-seeking, seeking new customers to maximize revenue' (R5); '<..> we pay monthly bonuses for the execution of the production plan and the outcome <...' (R21). The responses have revealed that the attributes of organizational incentive plans in the organizations surveyed are largely expressed through the various dimensions of corporate overall performance.

To summarize, it is necessary to state that some organizations, based on their size, might not have team-based incentive plans. Given this, it is important to identify which type of element creates value for the organization. As can be seen, individual performance covers all three themes but the company still creates an additional incentive plan to support the main focus and strategy. In addition, the organization sector might play an important role for setting up these plans. Public sector organizations are very limited to create such remuneration-based incentive plans, leading to the other characteristic of the flexibility of the remuneration system.

\subsection{The Flexibility of the Remuneration System}

The nature of the flexibility of the remuneration pay system is linked to the key adaptation processes related to organizational changes. Analyzing the respondents' answers to the question of how quickly your organization would be able to transform its remuneration system, 2 categories were identified: the flexible remuneration system and the stable 
remuneration system (Table 7).

Table 7. Sub-themes and themes that relate to flexibility of remuneration system

\begin{tabular}{|l|l|l|}
\hline Sub-Themes & Themes & Characteristic \\
\hline $\begin{array}{l}\text { Could be replaced within a short } \\
\text { period of time; easily adaptable to the } \\
\text { changing situation, does not require } \\
\text { large amount of resources; quick } \\
\text { decision-making and action-taking. }\end{array}$ & $\begin{array}{l}\text { Flexible remuneration } \\
\text { system }\end{array}$ & $\begin{array}{l}\text { Flexibility of the } \\
\text { remuneration system }\end{array}$ \\
\hline $\begin{array}{l}\text { Changes to remuneration system are } \\
\text { time-consuming; additional resources } \\
\text { required; difficult decision making } \\
\text { and overcoming }\end{array}$ & Stable remuneration & \\
system & & \\
\hline
\end{tabular}

The distinction between the two categories reflects the speed with which companies' remuneration systems can be changed when needed. The answers in the first category show that the remuneration system can be changed in a short time, easily adapted to the changed situation, does not require much additional resources, and the process is speeded up by quick decision-making. Emphasizing remuneration flexibility, respondents note that, if necessary, changing the company's current remuneration system would not be difficult: '〈... very quickly and easily; <...> adjusting this system or making another system, writing down counting and that is it, <...> payroll could be calculated on another system starting the following month.' (R5). During the interviews, it was noticed that changing of the remuneration system in organizations would not require any substantial time, human and material resources: '〈...> is part of our work and we do not see it as extra time to change something. It is simply a constant principle of growth in the organization<...>' (R2). Respondents also stressed the great influence on flexibility followed by management board responsibility and constant monitoring of the remuneration system: ' $<\ldots\rangle$ fast. If the CEO will say from tomorrow we do so' (R9); '<...> every year we carry out $<\ldots>$ a survey of the remuneration salary market $\langle. . .>$ and at all times trying to make that system as relevant as possible <...> in relation to the remuneration of the whole market. <...> it would be very easy for us to deal with it quickly' (R6).

The second category of answers emphasizes that remuneration modifications require a lot of time and additional resources: ' $<\ldots>$ This is certainly not a quick process. $<\ldots>$ It would take about 1-1.5 y. <...> an additional specialist post in the personnel unit would be required' (R14); '<...> to that, we would look for professional help from outside <...>' (R7). The statements made by the respondents have revealed that the change of the remuneration system of the investigated organizations is highly dependent on the capabilities and formal bureaucratic constraints, which result in more complexity, resources and contact time within the stakeholders required: '<..> for the change the heads of the departments concerned, 
analytics, finance teams, commerce are being implemented. The offer is approved by the union and the CEO, so many employees need to be contacted and usually such adjustments take time' (R4); '<...> It would take a considerable amount of time and effort to prepare and deal with relevant sections on the new versions of the orders and regulations $<\ldots>$ ' (R13).

Development of this characteristic disclosed that there are 3 key indicators in this category: time, resources (excl. time) and decision-making. Based on the findings, the authors raise the idea that flexibility might be related to certain levels and dependencies on different indicators. It could be critically assessed if the organization reaches decent values for a certain level of flexibility. The first case could be an example of an organization which has the resources for a quick change of remuneration system, yet the hierarchy and bureaucracy do not allow to change the system due to the decision process; on the contrary, some organizations can make a fast decision on change but need additional resources which might not be planned in budgets. For the second case a special tool might be created which states decent indicators determining if organization remuneration system is stable or flexible. An organization needs to meet all of them to reach a certain flexibility level.

The research has uncovered that theoretically disclosed core characteristics might not be sufficient and constant development is required. The results of the qualitative study have confirmed all five characteristics of the remuneration system and significantly expanded on the list of their indicators. Interviews disclosed 42 additional indicators and 1 feature. The final characteristics are revealed in the table (Appendix 1). These core remuneration system characteristics contribute to the remuneration system construct and also provide design for sustainable human resource management principles.

\subsection{Links Between SHRM Principles and Remuneration System Characteristics}

Empirical research has identified features of remuneration system characteristics and their indicators were used to identify links with SHRM principles (Table 8).

Table 8. Empirically tested links between SHRM principles and remuneration system characteristics

\begin{tabular}{|l|l|l|l|l|}
\hline $\begin{array}{c}\text { SHRM } \\
\text { principles } \\
\text { (Stankevičiutė, } \\
\mathbf{2 0 1 5} \text { ) }\end{array}$ & SHRM features & \multicolumn{1}{|c|}{ Indicators } & $\begin{array}{l}\text { Features of } \\
\text { remuneration } \\
\text { system } \\
\text { characteristics }\end{array}$ & $\begin{array}{l}\text { Remuneration } \\
\text { system } \\
\text { characteristics }\end{array}$ \\
\hline HR preservation & $\begin{array}{l}\text { Employee- } \\
\text { friendly physical } \\
\text { environment }\end{array}$ & $\begin{array}{l}\text { Compliance } \\
\text { with safety } \\
\text { requirements }\end{array}$ & $\begin{array}{l}\text { Individual } \\
\text { incentive plans }\end{array}$ & $\begin{array}{l}\text { Remuneration } \\
\text { system } \\
\text { orientation } \\
\text { towards } \\
\text { performance }\end{array}$ \\
\hline $\begin{array}{l}\text { Environmental } \\
\text { protection }\end{array}$ & $\begin{array}{l}\text { Economical, } \\
\text { environmentally } \\
\text { friendly } \\
\text { solutions }\end{array}$ & $\begin{array}{l}\text { Saving material } \\
\text { resources; } \\
\text { production } \\
\text { output of the } \\
\text { unit }\end{array}$ & $\begin{array}{l}\text { Team incentive } \\
\text { plans }\end{array}$ & $\begin{array}{l}\text { Remuneration } \\
\text { system } \\
\text { orientation } \\
\text { towards } \\
\text { performance }\end{array}$ \\
\hline
\end{tabular}




\begin{tabular}{|c|c|c|c|c|}
\hline \multirow[t]{2}{*}{$\begin{array}{l}\text { The pursuit of } \\
\text { economic } \\
\text { efficiency }\end{array}$} & \multirow[t]{2}{*}{$\begin{array}{l}\text { Profit as a } \\
\text { prerequisite for } \\
\text { the survival of } \\
\text { an organization }\end{array}$} & $\begin{array}{l}\text { Organizational } \\
\text { profit, market } \\
\text { growth; } \\
\text { company } \\
\text { turnover }\end{array}$ & $\begin{array}{l}\text { Organization } \\
\text { incentive plans }\end{array}$ & $\begin{array}{l}\text { Remuneration } \\
\text { system } \\
\text { orientation } \\
\text { towards } \\
\text { performance }\end{array}$ \\
\hline & & $\begin{array}{l}\text { Implementation } \\
\text { of the } \\
\text { organization's } \\
\text { strategy }\end{array}$ & $\begin{array}{l}\text { Organization } \\
\text { focused }\end{array}$ & $\begin{array}{l}\text { Purposes of the } \\
\text { remuneration } \\
\text { system }\end{array}$ \\
\hline \multirow[t]{2}{*}{$\begin{array}{l}\text { Sustainability } \\
\text { orientation }\end{array}$} & $\begin{array}{l}\text { Consistency } \\
\text { between } \\
\text { employee and } \\
\text { organizational } \\
\text { values / goals }\end{array}$ & $\begin{array}{l}\text { Balance } \\
\text { between } \\
\text { organizational } \\
\text { and employee } \\
\text { goals }\end{array}$ & $\begin{array}{l}\text { Alignment of } \\
\text { organizational } \\
\text { and employee } \\
\text { goals }\end{array}$ & $\begin{array}{l}\text { Purposes of the } \\
\text { remuneration } \\
\text { system }\end{array}$ \\
\hline & $\begin{array}{lr}\text { Fostering } & \text { a } \\
\text { sense } & \text { of } \\
\text { community }\end{array}$ & $\begin{array}{l}\text { Cooperating } \\
\text { organization }\end{array}$ & $\begin{array}{l}\text { Alignment of } \\
\text { organizational } \\
\text { and employee } \\
\text { goals }\end{array}$ & $\begin{array}{l}\text { Purposes of the } \\
\text { remuneration } \\
\text { system }\end{array}$ \\
\hline $\begin{array}{l}\text { Employee as an } \\
\text { equal partner }\end{array}$ & $\begin{array}{l}\text { The value of the } \\
\text { employee }\end{array}$ & $\begin{array}{l}\text { Competencies } \\
\text { and skills }\end{array}$ & $\begin{array}{l}\text { Soft } \\
\text { remuneration } \\
\text { goals }\end{array}$ & $\begin{array}{l}\text { Orientation } \\
\text { towards } \\
\text { remuneration } \\
\text { goals }\end{array}$ \\
\hline \multirow[t]{3}{*}{$\begin{array}{l}\text { Respect for the } \\
\text { employee }\end{array}$} & $\begin{array}{l}\text { Meaning of } \\
\text { equal } \\
\text { opportunities }\end{array}$ & $\begin{array}{l}\text { Attracting and } \\
\text { retaining the } \\
\text { best employees }\end{array}$ & $\begin{array}{l}\text { Employee- } \\
\text { focused }\end{array}$ & $\begin{array}{l}\text { Purposes of the } \\
\text { remuneration } \\
\text { system }\end{array}$ \\
\hline & $\begin{array}{l}\text { Constructive } \\
\text { coordination of } \\
\text { the interests of } \\
\text { the organization } \\
\text { and the } \\
\text { employee }\end{array}$ & $\begin{array}{l}\text { The pay is based } \\
\text { on a confidential } \\
\text { agreement with } \\
\text { the supervisor }\end{array}$ & $\begin{array}{l}\text { Semi- or } \\
\text { completely } \\
\text { non-formalized }\end{array}$ & $\begin{array}{l}\text { Formalization of } \\
\text { the } \\
\text { remuneration } \\
\text { system }\end{array}$ \\
\hline & $\begin{array}{l}\text { Transparency of } \\
\text { labor relations }\end{array}$ & $\begin{array}{l}\text { The } \\
\text { remuneration } \\
\text { system is based } \\
\text { on the } \\
\text { evaluation of } \\
\text { positions, the } \\
\text { remuneration } \\
\text { structure covers } \\
\text { all the work / } \\
\text { positions of the } \\
\text { organization, } \\
\text { acquaintance of } \\
\text { employees with } \\
\text { descriptions }\end{array}$ & Well-formalized & $\begin{array}{l}\text { Formalization of } \\
\text { the } \\
\text { remuneration } \\
\text { system }\end{array}$ \\
\hline
\end{tabular}




\begin{tabular}{|c|c|c|c|c|}
\hline Flexibility & Mobility & $\begin{array}{l}\text { Easy to adapt to } \\
\text { changes in the } \\
\text { situation, does } \\
\text { not require large } \\
\text { resources, quick } \\
\text { decision-making } \\
\text { and } \\
\text { implementation }\end{array}$ & $\begin{array}{l}\text { Flexible } \\
\text { remuneration } \\
\text { system }\end{array}$ & $\begin{array}{l}\text { Flexibility of the } \\
\text { remuneration } \\
\text { system }\end{array}$ \\
\hline \multirow[t]{2}{*}{$\begin{array}{l}\text { Employee } \\
\text { cooperation }\end{array}$} & $\begin{array}{l}\text { Employee } \\
\text { cooperation is } \\
\text { encouraged }\end{array}$ & $\begin{array}{l}\text { Productivity of } \\
\text { teamwork }\end{array}$ & $\begin{array}{l}\text { Team incentive } \\
\text { plans }\end{array}$ & $\begin{array}{l}\text { Remuneration } \\
\text { system } \\
\text { orientation } \\
\text { towards } \\
\text { performance }\end{array}$ \\
\hline & $\begin{array}{l}\text { Non-competing } \\
\text { employees }\end{array}$ & Team indicators & $\begin{array}{l}\text { Team incentive } \\
\text { plans }\end{array}$ & $\begin{array}{l}\text { Remuneration } \\
\text { system } \\
\text { orientation } \\
\text { towards } \\
\text { performance }\end{array}$ \\
\hline \multirow[t]{2}{*}{$\begin{array}{l}\text { Employee } \\
\text { participation }\end{array}$} & $\begin{array}{ll}\text { Suggestions } & \text { for } \\
\text { improving } & \text { the } \\
\text { production } & \\
\text { process } & \end{array}$ & $\begin{array}{l}\text { Performance } \\
\text { improvement, } \\
\text { involvement in } \\
\text { internal } \\
\text { organizational } \\
\text { processes }\end{array}$ & $\begin{array}{l}\text { Organization- } \\
\text { focused }\end{array}$ & $\begin{array}{l}\text { Purposes of the } \\
\text { remuneration } \\
\text { system }\end{array}$ \\
\hline & $\begin{array}{l}\text { Motivating } \\
\text { employees to } \\
\text { participate }\end{array}$ & $\begin{array}{l}\text { Employee } \\
\text { motivation, } \\
\text { remuneration for } \\
\text { the achieved } \\
\text { result }\end{array}$ & $\begin{array}{l}\text { Employee- } \\
\text { focused }\end{array}$ & $\begin{array}{l}\text { Purposes of the } \\
\text { remuneration } \\
\text { system }\end{array}$ \\
\hline \multirow[t]{3}{*}{$\begin{array}{l}\text { Employee } \\
\text { potential } \\
\text { development }\end{array}$} & $\begin{array}{l}\text { More efficient } \\
\text { performance of } \\
\text { work functions }\end{array}$ & $\begin{array}{l}\text { Employee } \\
\text { behavior is } \\
\text { favourable to the } \\
\text { organization }\end{array}$ & $\begin{array}{l}\text { Employee- } \\
\text { focused }\end{array}$ & $\begin{array}{l}\text { Purposes of the } \\
\text { remuneration } \\
\text { system }\end{array}$ \\
\hline & $\begin{array}{l}\text { Decrease in } \\
\text { organizational } \\
\text { costs }\end{array}$ & $\begin{array}{l}\text { Labor } \\
\text { control }\end{array}$ & $\begin{array}{l}\text { Organization- } \\
\text { focused }\end{array}$ & $\begin{array}{l}\text { Purposes of the } \\
\text { remuneration } \\
\text { system }\end{array}$ \\
\hline & $\begin{array}{l}\text { Work quality } \\
\text { assurance }\end{array}$ & $\begin{array}{l}\text { Quality, number } \\
\text { of errors }\end{array}$ & $\begin{array}{l}\text { Hard } \\
\text { remuneration } \\
\text { goals }\end{array}$ & $\begin{array}{l}\text { Orientation } \\
\text { towards } \\
\text { remuneration } \\
\text { goals }\end{array}$ \\
\hline
\end{tabular}

The analysis of the interviews has revealed that as many as 10 of the 12 SHRM principles singled out by Stankevičiūte (2015) allow to identify the remuneration system as a sustainable work system. Individual indicators of the features of the characteristics of the remuneration system have links with the characteristics of the SHRM principles. The orientation towards remuneration goals fulfils the principle of developing the potential of employees through hard goals aimed at ensuring the quality of work, and through soft goals 
giving meaning to the value of employees, revealing the principle of the employee as an equal partner. The indicators of the characteristic of purposes of the remuneration system demonstrate the expression of several SHRM principles in remuneration systems. Organization- and employee-oriented goals ensure the principles of respect for employees, employee participation and employee potential development in different aspects. Organization-oriented goals emphasize the pursuit of economic efficiency. Meanwhile, the newly identified feature of alignment of organizational and employee goals reveals the principle of sustainability through the coherence of employee and organizational values/ goals and the fostering of a sense of community. The characteristic of formalization of the remuneration system from different perspectives reveals the principle of respect for the employee. Formalized remuneration systems satisfy respect for employees through an emphasis on transparent employment relationships, and informal/ semi-formalized ones through a constructive balance between the interests of the organization and the employee. The characteristic of remuneration system orientation towards performance reveals the expression of all three aspects of sustainability (economic, social and environmental). Organization incentive plans through the provision of profit as a necessary condition for the survival of the organization satisfy the pursuit of economic efficiency, team incentive plans ensure environmental sustainability through economical, environmentally friendly solutions, individual incentive plans save human resources through ensuring an employee-friendly physical environment. Team incentive plans also focus on the implementation of the principle of cooperation of SHRM employees. The characteristic of flexibility of the remuneration system is directly related to the disclosure of the principle of flexibility, ensuring the adaptability of the remuneration system itself to changing conditions.

The results of the qualitative research provide insights into the sustainability of remuneration systems. All five characteristics of the remuneration system have revealed various principles of SHRM through different characteristics and indicators and confirm the economically, socially and environmentally sustainable nature of remuneration systems.

\section{Discussion}

Analysis of scientific literature has shown that the majority of research on sustainable remuneration systems is descriptive, lacking empirical insights. There is a lack of qualitative research that allows to look at the object of research in a complex way, looking from different prisms of approach. An empirical study has confirmed the claim of Hahn and Figge (2011) and other researchers that sustainability at the organizational level is a complex, multi-faceted construct that determines environmental, social, and economic outcomes. The research also confirmed the expression of all three aspects of sustainability in remuneration systems. The ideas of economic, social and environmental sustainability are realized through separate characteristics of the remuneration system. The study of the characteristics of the remuneration system revealed that based on the indicators refined in the study, it is possible to define not only the indicators of the characteristics of the remuneration system, but also the features of SHRM principles (Stankevičiūtè, 2015). Meanwhile, authors deepened knowledge on the sustainability idea addressing sustainable work systems (Eijnatten, 2000; Docherty, et el. 2002). Hence, the linkage of sustainable human resource (Wright, \& McMahan, 1992) to 
the characteristics of remuneration systems was already theoretically addressed. The main linkage belongs to the remuneration system construct, directly interlinked within work systems which may or may not have sustainability in them. The empirical research has revealed how current sustainable human resource management could be affected by simply challenging the characteristics of the remuneration system. Given this, all remuneration system characteristics provide a decent input towards sustainability rating of an organization. The authors of this empirical research have revealed the importance of characteristics of remuneration systems towards sustainable human resource management by using a managerial approach instead of financial or legislative.

\section{Conclusion}

The article provides empirical insights into the sustainability of the remuneration system. The value of the article is based on two main results: first, empirically confirmed characteristics of the remuneration system, revealing its features and indicators, second, defined the sustainability of the remuneration system through the links between remuneration system characteristics and SHRM principles.

The added value of this empirical research includes revealing and supplementing with new features and indicators the key characteristics of remuneration systems which contribute to sustainable human resources management in an organization:

- The orientation towards remuneration system goals confirmed theoretical insights and corresponded to the idea that different organizations might have different approaches. 12 new indicators, such as additional employee responsibilities, employee initiative and others were identified.

- Previous theoretical dispersion of the criteria regarding the purposes of remuneration system challenged the authors during the research. Thus, a new category was identified in which the organization tries to align the organizational and employee focuses. In this case, a certain grading from organizational to employee focus might be revealed, but the need of balance has been identified. In addition, 9 new indicators, such as performance improvement, attracting and retaining the best employees, collaborative organization and others were determined.

- The characteristic of formalization of the remuneration system confirmed primary theoretical insights that the formalization level might only be increased having sufficient resources. The research has revealed 4 new indicators of the remuneration system: basis on job evaluation, documentation of the remuneration system in the internal records of the organization, staff briefing and pay based on a confidential agreement with the head. However, the focus mainly belongs to the assessment of individual positions.

- The remuneration system orientation towards performance determined and confirmed the importance of incentive plans. These plans disclose the key focus of added value. The sector of organization plays a significant role because of practical issues concerning budgeting and creation of incentive plans. For this characteristic 13 new 
indicators were identified.

- Development of the characteristic of flexibility of the remuneration system determined 3 main elements leading to a certain assessment of flexibility which are: time, resources (excl. time) and decision-making. This approved the characteristic, but still challenged the authors on an assessment tool. Indicators of part of direct labor, constant salary market research, additional specialist occupation in HR unit and outside help from professionals were identified.

The features and indicators of remuneration systems revealed by the qualitative study allowed to refine the expression of SHRM principles in remuneration systems. The results of the qualitative study provide insights into the sustainability of remuneration systems, stating that they have all three aspects of sustainable management, economic, social and environmental features, through the implementation of different SHRM principles:

- The social dimension of sustainable management is being reflected by the characteristics of Orientation towards remuneration goals, Purposes of remuneration system, Formalization of remuneration system, Remuneration system orientation towards performance, Flexibility of remuneration system.

- The economic aspect of sustainable management is being reflected by the characteristics of Purposes of remuneration system, Remuneration system orientation towards performance, Flexibility of remuneration system.

- The environmental dimension of sustainable management is being reflected by the characteristics of Purposes of remuneration system, Remuneration system orientation towards performance.

Empirical validation of these links establishes guidelines for further research into the sustainability of remuneration systems.

\section{References}

Abraham, M. (2017). Pay formalization revisited: Considering the effects of manager gender and discretion on closing the gender wage gap. Academy of Management Journal, 60(1), 29-54. https://doi.org/10.5465/amj.2013.1060

Armstrong, M. (2009). Armstrong's handbook of human resource management practice. London: Kogan Page.

Armstrong, M., \& Taylor, S. (2017). Armstrongs handbook of human resource management practice. London: Kogan Page.

Armstrong, M., \& Cummins, A. (2011). The reward management toolkit: a step-by-step guide to designing and delivering pay and benefits. London: Kogan Page.

Armstrong, M., \& Murlis, H. (2007). Reward management A handbook of reumeration strategy and practice. London: Kogan Page.

Babecký, J., Galuščák, K., \& Žigraiová, D. (2017). Wage dynamics and financial 
performance: Evidence from Czech firms. Czech National Bank, Research Department.

Becker, W. (2011). Are You Leading a Socially Responsible and Sustainable Human Resource Function? People \& Strategy, 34(1), 18. Available: https://ssrn.com/abstract=2118903 (April 9, 2020).

Becker, W. S., \& Smith, R. J. (2012). Social and Environmental Responsibility, Sustainability, and Human Resource Practices. SSRN Electronic Journal. https://dx.doi.org/10.2139/ssrn.2120195

Biswas, B. D. (2013). Compensation and benefit design. USA: Financial Times Prentice.

Brundtland Report. (1987). Encyclopedia of Environment and Society. http://dx.doi.org/10.4135/9781412953924.n117

Costa, P. L., Passos, A. M., \& Bakker, A. B. (2014). Team work engagement: A model of emergence. Journal of Occupational and Organizational Psychology, 87(2), 414-436. https://doi.org/10.1111/joop.12057

Docherty, P., Forslin, J., \& Shani, A. B. (Eds.). (2002). Creating sustainable work systems: emerging perspectives and practice. Psychology Press. https://doi.org/10.4324/9780203995389

Dubinas, V. (1996). Darbo užmokesčio formos ir sistemos Europos šalyse. Vilnius: Lietuvos informacijos institutas.

Ehnert, I., Parsa, S., Roper, I., Wagner, M., \& Muller-Camen, M. (2015). Reporting on sustainability and HRM: a comparative study of sustainability reporting practices by the worlds largest companies. The International Journal of Human Resource Management, 27(1). 88-108. https://doi.org/10.1080/09585192.2015.1024157

Eijnatten, van, F. M. (2000). From intensive to sustainable work systems: The quest for a new paradigm of work. In M. Sapir (Ed.), Conference proceedings: Working without limits? Re-organising work and reconsidering workers' health: Plenary sessions. (pp. 47-66). Brussel.

Favilukis, J., \& Lin, X. (2016). Does wage rigidity make firms riskier? Evidence from long-horizon return predictability. Journal of Monetary Economics, 78, 80-95. https://doi.org/10.1016/j.jmoneco.2016.01.003

Ferreira, P. (2019). Market competition and executive pay. IZA World of Labor. https://doi.org/10.15185/izawol.115.v2

Flannery, T. P., Hofrichter, D. A., \& Platten, P. E. (1996). People, performance, and pay: dynamic compensation for changing organizations. New York: Free Press.

Fuller, S., \& Cooke, L. P. (2018). Workplace Variation in Fatherhood Wage Premiums: Do Formalization and Performance Pay Matter? Work, Employment and Society, 32(4), 768-788. https://doi.org/10.1177/0950017018764534 


\section{Ml Macrothink}

International Journal of Human Resource Studies ISSN 2162-3058 2020, Vol. 10, No. 2

Greenwood, M. R., \& Simmons, J. (2004). A Stakeholder Approach to Ethical Human Resource Management. Business and Professional Ethics Journal, 23(3), 3-23. https://doi.org/10.5840/bpej200423313

Gryglewicz, S., Hartman-Glaser, B., \& Zheng, G. (2018). Growth Options, Incentives, and Pay-for-Performance: Theory and Evidence. SSRN Electronic Journal. http://dx.doi.org/10.2139/ssrn.293871

Hahn, T., \& Figge, F. (2011). Beyond the bounded instrumentality in current corporate sustainability research: toward an inclusive notion of profitability. Journal of Business Ethics. 104. 325-345. https://doi.org/10.1007/s10551-011-0911-0

Henderson, R. I. (2006). Compensation management in a knowledge-based world. Upper Saddle River, NJ: Pearson/Prentice Hall.

Holmström, B. (2017). Pay for performance and beyond. American Economic Review, 107(7). 1753-77. https://doi.org/10.1257/aer.107.7.1753

Kira, M. (2003). From Good Work to Sustainable Development - Human Resources Consumption and Regeneration in the Post-Bureaucratic Working Life ( $\mathrm{PhD}$ dissertation). Industriell ekonomi och organisation, Stockholm. Available: http://urn.kb.se/resolve?urn=urn:nbn:se:kth:diva-3500 (April 9, 2020).

Kuvaas, B., Buch, R., \& Dysvik, A. (2018). Individual variable pay for performance, incentive effects, and employee motivation. In annual meeting of the Academy of Management. Chicago, USA.

Larkin, I. (2019). Strategic compensation: a critique and research agenda. Handbook of Research on Strategic Human Capital Resources Glos: Edward Elgar Publishing Limited. p. 403-424. https://doi.org/10.4337/9781788116695.00039

Legge, K. (1998). Is HRM ethical? Can HRM be ethical? In M. Parker (Ed.), Ethics and organizations. London: Sage. p. 150-172.

Lélé, S. M. (1991). Sustainable development: A critical review. World Development, 19(6). 607-621. https://doi.org/10.1016/0305-750X(91)90197-P

Lipinskienè, D. (2012). Motyvuojanti atlygio sistema: vadovėlis. Kaunas: Technologija.

Macke, J., \& Genari, D. (2018). Systematic Literature Review on Sustainable Human Resource Management. Journal of Cleaner Production, 208, 806-815. https://doi.org/10.1016/j.jclepro.2018.10.091.

Mačernytè-Panomariovienè, I. (2003). Apmokëjimas už darba ir jo užtikrinimas: mokomasis leidinys. Vilnius: LTU leidybos centras.

Mäkikangas, A., Aunola, K., Seppälä, P., \& Hakanen, J. (2016). Work engagement-team performance relationship: shared job crafting as a moderator. Journal of Occupational and Organizational Psychology, 89(4), 772-790. https://doi.org/10.1111/joop.12154 
Martocchio, J. J. (2013). Strategic compensation: a human resource management approach. Boston, MA: Pearson.

Mayring, P. H. (2014). Qualitative content analysis: theoretical foundation, basic procedures and software solution. Monographie. Klagenfurt. https://doi.org/10.1007/978-94-017-9181-6_13

Milkovich G. T., Newman J. M., \& Gerhart B. (2014). Compensation. New York: McGraw-Hill/Irwin.

Olawumi, T. O., \& Chan, D. W. (2018). A scientometric review of global research on sustainability and sustainable development. Journal of Cleaner Production, 183, 231-250. https://doi.org/10.1016/j.jclepro.2018.02.162

Opatha, H. H. D. N. P., \& Arulrajah, A. A. (2014). Green Human Resource Management: Simplified General Reflections. International Business Research, 7(8). http://dx.doi.org/10.5539/ibr.v7n8p101

Poria, Y., Reichel, A., \& Brandt, Y. (2011). Dimensions of hotel experience of people with disabilities: an exploratory study. International Journal of Contemporary Hospitality Management, 23(5), 571-591. https://doi.org/10.1108/09596111111143340

Radvila, G., \& Šilingienè, V. (2018). Characteristics of remuneration systems of organizations for sustainable human resource management: Theoretical approach. CISABE'2018: 7th International Conference on Changes in Social and Business Environment, April 26-27, 2018, Panevėžys, Lithuania, 103-112.

Renwick, D. W., Redman, T., \& Maguire, S. (2012). Green Human Resource Management: A Review and Research Agenda. International Journal of Management Reviews, 15(1), 1-14. https://doi.org/10.1111/j.1468-2370.2011.00328.x

Sauer, S. J., Rodgers, M., \& Becker, W. J. (2018). The Effects of Goals and Pay Structure on Managerial Reporting Dishonesty. Journal of Accounting, Ethics and Public Policy, 19(3). Available: https://ssrn.com/abstract=3256350 (April 9, 2020).

Schmitt-Grohé, S., \& Uribe, M. (2016). Downward Nominal Wage Rigidity, Currency Pegs, and Involuntary Unemployment. Journal of Political Economy, 124(5), 1466-1514. http://dx.doi.org/10.1086/688175

Shani, A. B., \& Docherty, P. (2003). Learning by design: building sustainable organizations. Oxford: Blackwell.

Stankevičiūtè, Ž. (2015). Tvarumo dimensija organizacijos žmonių išteklių valdyme (PhD dissertation). Kauno technologijos universitetas, Kaunas.

Sundberg, D. B. (2015). "The Effects of Incentive Pay Systems with Tiered Goals on Performance". $\quad$ Dissertations. $542 . \quad$ Available: https://scholarworks.wmich.edu/dissertations/542 (April 9, 2020).

Thanassoulis, J., \& Tanaka, M. (2018). Optimal Pay Regulation for Too-Big-to-Fail Banks. 
Journal of Financial Intermediation, 33, 83-97. https://doi.org/10.1016/j.jfi.2017.03.001

Trif, A., \& Geary, J. (2016). The purpose of variable pay schemes and trade unions. Employee Relations, 38(2), 182-199. https://doi.org/10.1108/ER-01-2015-0004

Vanagas, P. (2009). Darbo organizavimas, normavimas ir atlyginimas už darbą: vadovèlis. Kaunas: Technologija.

Wang, T., Zhao, B., \& Thornhill, S. (2015). Pay dispersion and organizational innovation: The mediation effects of employee participation and voluntary turnover. Human Relations, 68(7). 1155-1181. https://doi.org/10.1177/0018726715575359

Wang, T., Thornhill, S., \& Zhao, B. (2016). Pay-for-Performance, Employee Participation, and SME Performance. Journal of Small Business Management, 56(3), 412-434. https://doi.org/10.1111/jsbm.12268

Wright, P. M., \& McMahan, G. C. (1992). Theoretical perspectives for strategic human resource management. Journal of management, 18(2). 295-320. https://doi.org/10.1177/014920639201800205

\section{Appendix}

Appendix 1. The summary of remuneration system characteristics, features and indicators

\begin{tabular}{|c|c|c|c|c|}
\hline $\begin{array}{c}\text { Characteristics } \\
\text { of the } \\
\text { remuneration } \\
\text { system }\end{array}$ & $\begin{array}{l}\text { Characteristics } \\
\text { of the } \\
\text { remuneration } \\
\text { system revealed } \\
\text { in theoretical } \\
\text { part, which have } \\
\text { been confirmed } \\
\text { during the } \\
\text { exploratory } \\
\text { qualitative } \\
\text { research }\end{array}$ & $\begin{array}{c}\text { New features } \\
\text { of the } \\
\text { remuneration } \\
\text { system } \\
\text { revealed in } \\
\text { qualitative } \\
\text { exploratory } \\
\text { research }\end{array}$ & $\begin{array}{l}\text { Indicators } \\
\text { revealed in } \\
\text { theoretical part } \\
\text { that have been } \\
\text { confirmed } \\
\text { during the } \\
\text { exploratory } \\
\text { qualitative } \\
\text { research }\end{array}$ & $\begin{array}{l}\text { New indicators } \\
\text { revealed during the } \\
\text { exploratory } \\
\text { qualitative research }\end{array}$ \\
\hline \multirow[t]{2}{*}{$\begin{array}{l}\text { Orientation } \\
\text { towards } \\
\text { remuneration } \\
\text { goals }\end{array}$} & $\begin{array}{l}\text { Soft remuneration } \\
\text { goals }\end{array}$ & & $\begin{array}{l}* \text { competences } \\
* \text { professional } \\
\text { knowledge }\end{array}$ & $\begin{array}{l}\text { * additional employee } \\
\text { responsibilities } \\
\text { * employee initiative } \\
\text { * employee efforts } \\
\text { * employee } \\
\text { development } \\
\text { * work experience }\end{array}$ \\
\hline & $\begin{array}{l}\text { Hard } \\
\text { remuneration } \\
\text { goals }\end{array}$ & & $\begin{array}{l}* \text { results } \\
* \text { contribution to } \\
\text { company results }\end{array}$ & $\begin{array}{l}\text { * individual sales } \\
\text { results } \\
\text { * number of shipments } \\
\text { delivered } \\
\text { * number of errors } \\
\text { * benefit to the } \\
\text { enterprise of the } \\
\text { employee's financial } \\
\text { result } \\
\text { * goals achieved by the } \\
\text { employee } \\
\text { * quality } \\
\text { * productivity }\end{array}$ \\
\hline $\begin{array}{l}\text { Purposes of the } \\
\text { remuneration }\end{array}$ & $\begin{array}{l}\text { Organization- } \\
\text { focused }\end{array}$ & & $\begin{array}{l}\text { * involvement in } \\
\text { internal }\end{array}$ & $\begin{array}{l}\text { * performance } \\
\text { improvement }\end{array}$ \\
\hline
\end{tabular}




\begin{tabular}{|c|c|c|c|c|}
\hline \multirow[t]{3}{*}{ system } & & & $\begin{array}{l}\text { organizational } \\
\text { processes } \\
* \text { labor cost } \\
\text { control } \\
\text { *implementation } \\
\text { of the } \\
\text { organization's } \\
\text { strategy }\end{array}$ & $\begin{array}{l}\text { * profit } \\
\text { * overall company } \\
\text { results }\end{array}$ \\
\hline & Employee-focused & & $\begin{array}{l}* \text { motivating } \\
\text { employees } \\
* \text { remuneration } \\
\text { for the result } \\
\text { achieved }\end{array}$ & $\begin{array}{l}\text { * attracting and } \\
\text { retaining the best } \\
\text { employees } \\
\text { * employee behavior } \\
\text { favorable to the } \\
\text { organization } \\
\text { * ideas for } \\
\text { improvement }\end{array}$ \\
\hline & & $\begin{array}{l}\text { Alignment of } \\
\text { organizational } \\
\text { and employee } \\
\text { goals }\end{array}$ & & $\begin{array}{l}\text { * balance between the } \\
\text { goals of the } \\
\text { organization and the } \\
\text { employees } \\
\text { * collaborative } \\
\text { organization } \\
\text { * delegation of } \\
\text { organization goals }\end{array}$ \\
\hline \multirow[t]{2}{*}{$\begin{array}{l}\text { Formalization } \\
\text { of remuneration } \\
\text { system }\end{array}$} & Well-formalized & & $\begin{array}{l}* \text { a clearly } \\
\text { defined } \\
\text { remuneration } \\
\text { structure } \\
* \text { remuneration } \\
\text { structure covers } \\
\text { all work / } \\
\text { positions of the } \\
\text { organization } \\
* \text { remuneration } \\
\text { structure covers } \\
\text { all work / } \\
\text { positions of the } \\
\text { organization }\end{array}$ & $\begin{array}{l}\text { * the remuneration } \\
\text { system is based on job } \\
\text { evaluation } \\
\text { * the payroll system is } \\
\text { documented in the } \\
\text { internal records of the } \\
\text { organization } \\
\text { * staff briefing }\end{array}$ \\
\hline & $\begin{array}{l}\text { Semi- or } \\
\text { completely } \\
\text { non-formalized }\end{array}$ & & $\begin{array}{l}* \text { only individual } \\
\text { payrolls are } \\
\text { recognized } \\
* \text { wages are } \\
\text { defined only in } \\
\text { the employment } \\
\text { contract }\end{array}$ & $\begin{array}{l}\text { * pay is based on a } \\
\text { confidential agreement } \\
\text { with the head }\end{array}$ \\
\hline \multirow[t]{2}{*}{$\begin{array}{l}\text { Remuneration } \\
\text { system } \\
\text { orientation } \\
\text { towards } \\
\text { performance }\end{array}$} & $\begin{array}{l}\text { Individual } \\
\text { incentive plans }\end{array}$ & & $\begin{array}{l}* \text { the } \\
\text { remuneration } \\
\text { system focuses } \\
\text { on individual } \\
\text { productivity } \\
\text { (quantity, } \\
\text { quality) } \\
* \text { monthly sales } \\
* \text { compliance } \\
\text { with } \\
\text { occupational } \\
\text { safety } \\
\text { requirements } \\
* \text { work discipline }\end{array}$ & $\begin{array}{l}\text { * employee behavior is } \\
\text { directed towards good } \\
\text { job performance } \\
\text { * annual performance } \\
\text { appraisal } \\
\text { * broke } \\
\text { * personal } \\
\text { achievements } \\
\text { * personal efforts }\end{array}$ \\
\hline & $\begin{array}{l}\text { Team incentive } \\
\text { plans }\end{array}$ & & $\begin{array}{l}* \text { the } \\
\text { remuneration }\end{array}$ & $\begin{array}{l}\text { * productivity of } \\
\text { teamwork }\end{array}$ \\
\hline
\end{tabular}




\begin{tabular}{|c|c|c|c|}
\hline & & $\begin{array}{l}\text { system is } \\
\text { oriented towards } \\
\text { the satisfaction } \\
\text { of consumers } \\
* \text { saving of pay } \\
\text { costs } \\
* \text { saving of } \\
\text { material } \\
\text { resources } \\
* \text { accident } \\
\text { prevention } \\
* \text { cost reduction } \\
\text { of services }\end{array}$ & $\begin{array}{l}\text { * team indicators } \\
* \text { unit profitability } \\
* \text { execution of unit } \\
\text { production plan } \\
* \text { unit production yield }\end{array}$ \\
\hline & $\begin{array}{l}\text { Organization } \\
\text { incentive plans }\end{array}$ & $\begin{array}{l}* \text { profits of the } \\
\text { organization } \\
* \text { cost savings } \\
* \text { market growth } \\
* \text { sales revenue }\end{array}$ & $\begin{array}{l}\text { * profits of the } \\
\text { organization } \\
\text { * fulfilment of the } \\
\text { company's production } \\
\text { plan; } \\
\text { * production output of } \\
\text { the company }\end{array}$ \\
\hline \multirow[t]{2}{*}{$\begin{array}{l}\text { Flexibility of } \\
\text { remuneration } \\
\text { system }\end{array}$} & $\begin{array}{l}\text { Flexible } \\
\text { remuneration } \\
\text { system }\end{array}$ & $\begin{array}{l}* \text { could be } \\
\text { replaced within a } \\
\text { short period of } \\
\text { time } \\
* \text { easily } \\
\text { adaptable to the } \\
\text { changing } \\
\text { situation } \\
* \text { does not } \\
\text { require large } \\
\text { amount of } \\
\text { resources } \\
* \text { quick } \\
\text { decision-making } \\
\text { and } \\
\text { action-taking }\end{array}$ & $\begin{array}{l}* \text { part of direct labor } \\
* \text { constant salary } \\
\text { market research }\end{array}$ \\
\hline & $\begin{array}{l}\text { Stable } \\
\text { remuneration } \\
\text { system }\end{array}$ & $\begin{array}{l}* \text { changes to } \\
\text { remuneration } \\
\text { system are } \\
\text { time-consuming } \\
* \text { additional } \\
\text { resources } \\
\text { required } \\
* \text { difficult } \\
\text { decision-making } \\
\text { and overcoming }\end{array}$ & $\begin{array}{l}\text { * additional specialist } \\
\text { occupation in HR unit } \\
\text { * outside help from } \\
\text { professionals }\end{array}$ \\
\hline
\end{tabular}

\section{Copyright Disclaimer}

Copyright for this article is retained by the author(s), with first publication rights granted to the journal.

This is an open-access article distributed under the terms and conditions of the Creative Commons Attribution license (http://creativecommons.org/licenses/by/4.0/). 